\title{
OSI və Cloud Computing Etalon Modellərinin Konvergentliyi
}

\author{
Zəfər Cəfərov \\ Azərbaycan Texniki Universiteti \\ Zafar.cafarov@bk.ru
}

\begin{abstract}
Xülasə- Məqalədə OSI və Cloud Computing etalon modelləri təhlil olunur. Bu modellərin konvergentliyini təmin edərək servisə yönəlik şəbəkə infrastrukturlarını inkişaf etdirmək üçün açıq proqram interfeyslərinin tətbiqinin mümkünlüyü göstərilir.
\end{abstract}

Açar sözlor - etalon model, OSİ, Cloud Computing, IaaS, PaaS, SaaS

\section{GİRİ̧}

Texniki inkişaf (çox-nüvəli prosessorlar və qiqant həcmli informasiya daşıyıcıları) və virtuallaşma texnologiyaları (virtual infrastruktur yaratmaq üçün proqram təminatı) sayəsində yeni servisə yönəlik "Bulud" (ing.,Cloud) modelləri yaranmışdir.

Provayder və istifadəçilər müxtəlif ölkələrə mənsub ola bildiklərinə görə Cloud Computing sahəsi üzrə beynəlxalq standartları təsvir edən etalon modelin mövcudluğu vacibidir. $\mathrm{Bu}$ model Milli Standartlar və Texnologiyalar İnstitutu (National Institute of Standards and Technology, NIST) tərəfindən təklif edilmişdir.

Bulud modelləri OSI və TCP/IP əsaslı Internetin istifadəsi və faylların şəbəkədə saxlanması üzrə texnologiyalarda dəyişikliklərə səbəb olmuşdur. Buna görə də OSI və Cloud Computing etalon modellərinin konvergentliyi zərurəti yaranır. Təqdim olunan işdə açıq proqram interfeyslərinin çoxsəviyyəli tətbiqi ilə OSI və Cloud Computing etalon modellərinin konvergentliyi təhlil olunur.

\section{OSI MODELINININ PROQRAM-APARAT TOMINATI}

Etalon model (ing. reference model) müəyyən tətbiq sahəsindəki anlayışların və onların arasında əlaqələrin mücərrəd təsviri hesab olunur. Etalon kimi təsvir olunan model daha dəqiq və təfsilatı qurulur ki, nəticədə mövcud obyekt və mexanizmləri real təmsil edir. Etalon model anlayışı informatikada geniş istifadə olunur.

İnformasiya-rabitə şəbəkələrinin açıqlığını və çevikliyini təmin etmək üçün Beynəlxalq Standartlaşdırma Təşkilatı (International Standards Organization , ISO) açıq sistemlərin qarşılıqlı əlaqəsinin etalon modelini (Open Systems Interconnection Reference Model, OSI) təklif (şəkil 1) etmişdir [1].

Açıqlıq mövcud texniki və proqram vasitələrini dəyişdirmədən yeni terminalların, rabitə kanallarının şəbəkəyə əlavə edilməsi imkanının olmasıdır. Çeviklik isə terminalların və ya rabitə vasitələrinin sıradan çıxması zamanı şəbəkənin fəaliyyətini davam etdirməsidir.

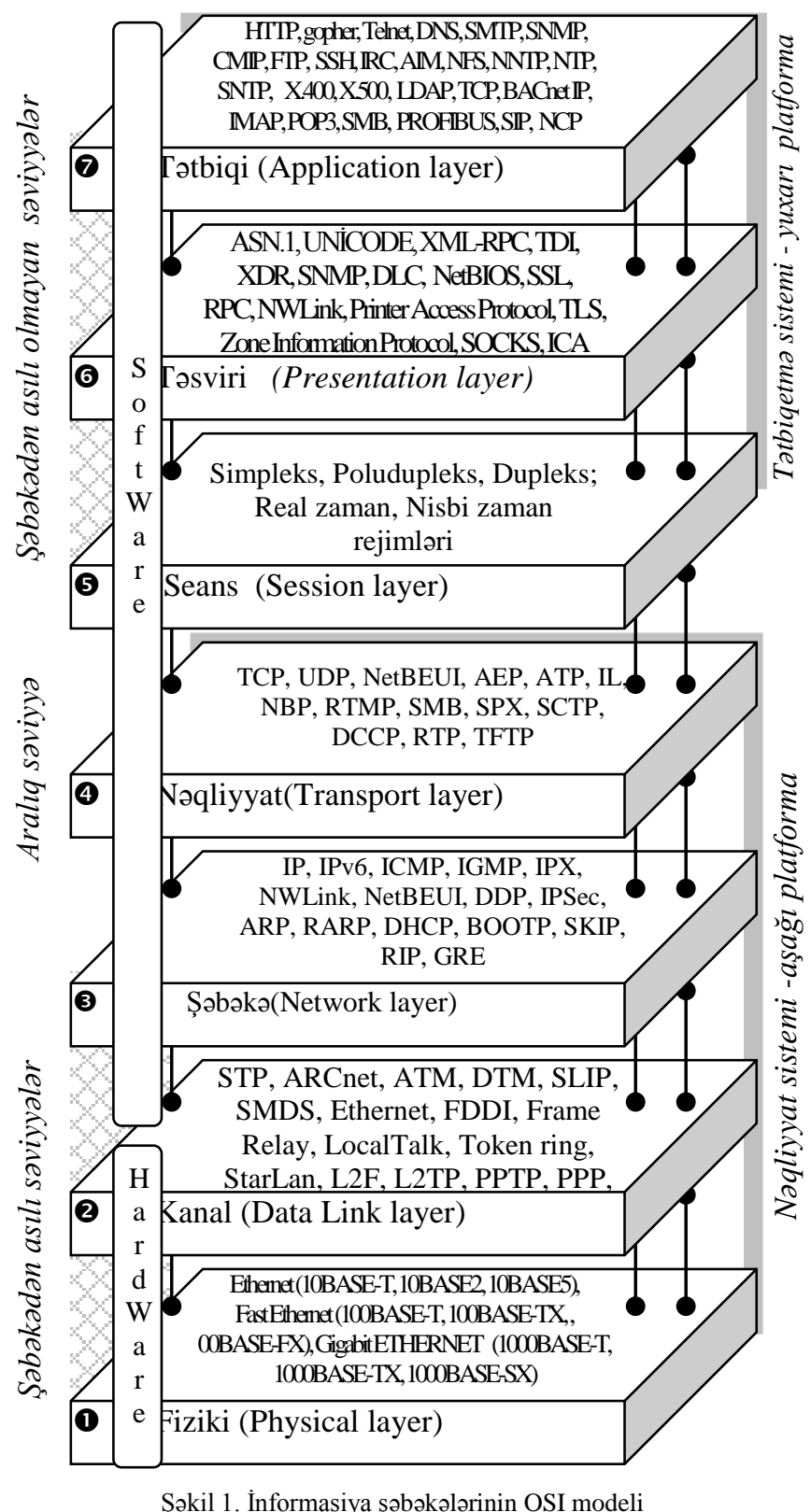

OSI modeli paket kommutasiyalı informasiya şəbəkələrinin aparat və proqram təminatının prinsiplərindən ibarətdir. Şəbəkə arxitekturunu təsvir edən OSI modelinin tələblərinə görə informasiya sistemlərinin qarşılıqlı əlaqəsi 7 səviyyə üzrə təşkil edilir. 
Adətən, aşağı iki səviyyyə funksiyaları aparat və proqram, yuxarıda qalan beş səviyyyə isə proqram vasitələri ilə reallaşdırılır. OSI modeli müxtəlif kompüterlərdə yerləşən tətbiqi proseslər arasında informasiyanın şəbəkə mühitinə mənsub yolla necə mübadilə olunmasını təsvir edir. OSI modeli paket kommutasiyalı şəbəkələrdə səviyyələrin qarşılıqlı fəaliyyətini təyin edir, onlara standart adlar verir və hər bir səviyyənin yerinə yetirəcəyi funksiyaları müəyyənləşdirir. $\mathrm{Bu}$ səviyyələrdə işləyən aparat, proqram və protokollar həmin funksiyaları yerinə yetirir. OSI modeli iki platformada tədbiq edilir (şəkil 1). Tətbiqetmə sistemi (Application Set), yuxarı platformaya 7-5 səviyyələri və nəqliyyat sistemi (Transport Set), aşağı platformaya isə 4-1 səviyyələri aiddir

\section{CLOUD COMPUTING SISTEMININ ETALON MODELI}

Cloud Computing, xidmətlərin təqdimi üzrə proqram təminatı, infrastruktur, platforma və s. kimi müxtəlif anlayışları özündə əks etdirən bir konsepsiyadır. Onun ən vacib funksiyası istifadəçilərin tələb və ehtiyaclarını ödəmək üçün verilənlərin tele-emalıdır.

Cloud Computing online xidmət kimi şəbəkə istifadəçilərinə kompüter resurslarını təqdim edən informasiya emalı texnologiyası hesab olunur. IEEE (Institute of Electrical and Electronics Engineers) sənədlərində bulud texnologiyas1 "istifadəçi məlumatlarını Internet serverlərində uzunmüddətli saxlayan və zəruri hallarda abunəçi tərəfinə müvəqqəti olaraq keşləşdirən texnologiya" kimi əks etdirilmişdir. Müştəri tərəfdə təkcə stasionar kompüter deyil, istənilən növ telekommunikasiya terminalı istifadə oluna bilər. İstifadəçi tətbiq olunan infrastruktur, proqram təminatının fərqinə varmadan şəbəkə vasitəsilə bu terminallardan məxsusi məlumatlarına çıxış əldə edir. Müəllif məxsusi məlumatlarını müsahiblərinə coğrafi yerlərindən asılı olmayaraq paylaşır və sənədlər üzərində birgə iş aparılır. İstifadəçi terminalının korlanması bulud yaddaşında saxlanan məlumatlara təsir etmir.

İlk olaraq NIST bulud paradiqmasına üç növ xidmət daxil etmiş̧dir (şəkil 2): IaaS, PaaS, SaaS.

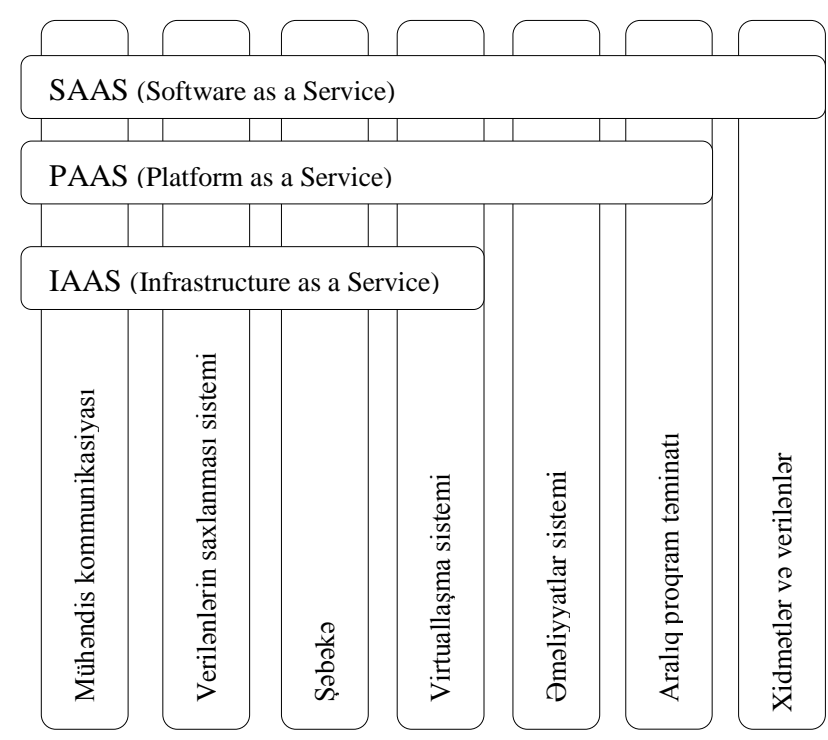

Şəkil 2. Cloud Computing servis modellərinin sxemi
Infrastruktur xidmət kimi (Infrastructure as a Service, IaaS) istifadəçiyə öz tələbatına uyğunlaşdıra biləcək resurslar (adətən şəbəkəyə bağlı bir virtual platforma) təqdim edir.

Platforma xidmət kimi (Platform as a Service, PaaS) istifadəçiyə əsasən əməliyyat sistemi və zəruri hallarda digər növ proqram təminatı quraşdırılmış kompüter sisteminə daxil olmaq imkanı yaradır.

Proqram təminatı xidmət kimi (Software as a Service, SaaS) şəbəkənin müxtəlif serverlərində yerləşmiş proqramlardan istifadə olunmasına imkanı yaradır. Bu xidmət növü yalnız proqramın faktiki istifadəsi üçün ödəniş tələb edir. Proqramların yenilənməsi və lisenziyalaşdırılması kimi məsələlər xidmət provayderinə aid olunur.

"Middleware Control" adlandirılan xüsusi proqram vasitəsilə bulud texnologiyasının xidmətlərini təqdim edən kompüterlərin birgə fəaliyyəti təmin olunur [2]. Bu proqram sistemin fəaliyyətində avadanlıqların vəziyyətini monitorinq edir və yükü balanslaşdırır.

NIST tərəfindən təklif edilən Cloud Computing üzrə etalon modeli müxtəlif funksional səviyyələrdə yerləşən müstəvilərin çoxluğu kimi təsvir etmək olar (şəkil 3).

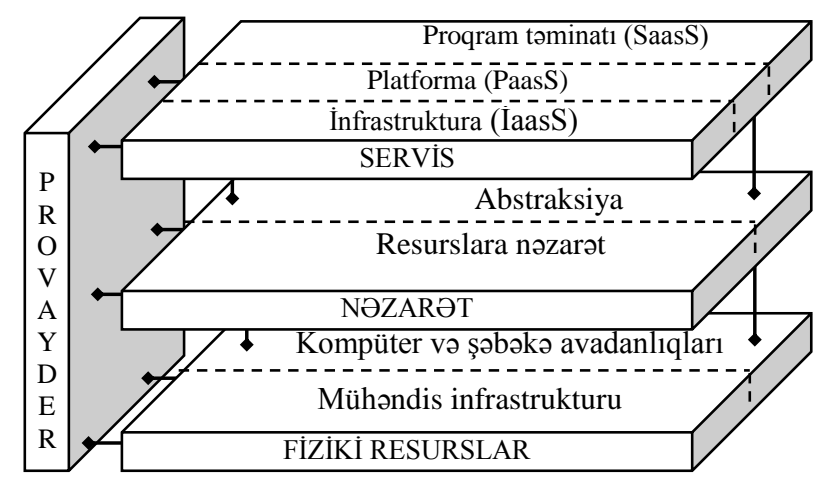

Şəkil 3. Cloud Computing sisteminin etalon modeli

Etalon modelin mərkəzində servis, nəzarət və fiziki resurlar səviyyələri, sol tərəfində bulud sisteminin təşkilatçısı olan provayder müstəvisi yerləşir.

Servis səviyyəsində (Service Layer) provayderin təqdim etdiyi bulud servisləri təyin olunur. Bu servislər üç baza modeli SPI (Software, Platform, Infrastructure as a Service) və törəmə modellər əsasında təqdim olunur [3].

Resursların abstraktsiya vo nozaroti saviyyəsindo (Resurs Abstraction va Control Level) hipervizor, virtual yaddaş və bulud servislərini təqdim etməyə imkan verən infrastrukturun təşkili üçün proqram təminatı elementləri yerləşdirilir.

Fiziki resurslar (Physical Level) səviyyəsindo zoruri texniki avadanlıqlar yerləşir:

$\checkmark$ Aparat tominatı (Hardware): Kompüter (CPU, HDD), şəbəkə (routerlər, firewall, kommutarorlar, rabitə kanalları, interfeyslər və s.), informasiya daşıyıcıları və hesablama infrastrukturunun digər fiziki elementləri. 
$\checkmark$ Mühandis infrastrukturu (Facilities): kondisioner sistemləri (HVAC), elektrik qida qurğuları (UPS daxil olmaqla), kommunikasiya vasitələri və fiziki platformanın (sahənin) təşkili üzrə digər zəruri elementlər.

\section{AÇIQ PROQRAM İNTERFEYSLORİ}

OSI modelli şəbəkədə qarşılıqlı şəffaf əlaqə yaratmaq üçün etalon modelin müxtəlif səviyyələri üzrə açıq proqram interfeysləri (Aplication Proqramm Interface, API) daxil edilir [4].

API interfeysləri elə yaradılır ki, onların vasitəsi ilə proqramlaşdırılan xidmətlər şəbəkənin daxilində tətbiq olunan protokol və texnologiyalardan asılı olmayaraq, müxtəlif rabitə mühitində icra oluna bilirlər. Bu konsepsiyaya görə paylanmış İKT (informasiya-kommunikasiya texnologiyaları) mühitində q1sa müddətdə yeni xidmətlərin yaradılması, yayılması və təqdim olunmasının funksional mexanizminin bir hissəsini rabitə şəbəkəsində qalması, qalanın isə kənar provayderlərə təqdim olunması imkanı yaranmışdır.

API interfeysləri müxtəlif şəbəkələrin resurslarının birgə istifadə olunmasında servis platformalarının şaquli modelindən imtina edərək, onların üfüqi arxitekturada konvergensiya dərəcəsini artırır (cədvəl 1).

CODVӘL 1. ŞəBӘKӘ STANDARTLARININ UYĞUNLUQLARI

\begin{tabular}{|c|c|c|}
\hline $\begin{array}{l}\mathrm{TCP} / \mathrm{IP} \\
\text { modeli }\end{array}$ & $\begin{array}{c}\text { OSI } \\
\text { modeli }\end{array}$ & $\begin{array}{c}\text { Cloud } \\
\text { Computing }\end{array}$ \\
\hline \multirow[t]{3}{*}{$\begin{array}{l}\text { I-Tətbiqi səviyyə } \\
\text { (Application Layer) }\end{array}$} & $\begin{array}{l}\text { 7-Tətbiqi səviyyə } \\
\text { (Application Layer) }\end{array}$ & \multirow[t]{3}{*}{ Servis } \\
\hline & $\begin{array}{l}\text { 6-Təsviri səviyyə } \\
\text { (Presentation Layer) }\end{array}$ & \\
\hline & $\begin{array}{l}\text { 5-Seans səviyyəsi } \\
\text { (Session Layer) }\end{array}$ & \\
\hline $\begin{array}{l}\text { II-Nəqliyyat } \\
\text { (Transport Layer) }\end{array}$ & $\begin{array}{l}\text { 4-Nəqliyyat səviyyəsi } \\
\text { (Transport Layer) }\end{array}$ & \multirow[t]{2}{*}{ Nəzarət } \\
\hline $\begin{array}{l}\text { III-Şəbəkə səviyyəsi } \\
\text { (Net- work Layer) }\end{array}$ & $\begin{array}{l}\text { 3-Şəbəkə səviyyəsi } \\
\text { (Network Layer) }\end{array}$ & \\
\hline \multirow{2}{*}{$\begin{array}{l}\text { IV -Şəbəkə } \\
\text { interfeysi səviyyəsi } \\
\text { (Network İnterface } \\
\text { Layer) }\end{array}$} & $\begin{array}{l}\text { 2-Kanal səviyyəsi } \\
\text { (Data-Link Layer) }\end{array}$ & \multirow[t]{2}{*}{ Fiziki Resurs } \\
\hline & $\begin{array}{l}\text { 1-Fiziki səviyyə } \\
\text { (Physical Layer) }\end{array}$ & \\
\hline
\end{tabular}

DOI: 10.25045/NCSoftEng.2017.06

\section{NəTİCə}

Cloud Computing, online xidmət kimi şəbəkə istifadəçilərinin tələb və ehtiyaclarını ödəmək üçün kompüter resurslarını təqdim edən informasiya emalı texnologiyası hesab edilir. O, İnternetin istifadəsi və faylların şəbəkədə saxlanması üzrə modellərdə dəyişikliklərə səbəb olmuşdur. Yeni servisə yönəlik Cloud modelləri OSI və Cloud Computing arxitekturlarının konvergensiyasını tələb edir. Bu prosesdə açıq proqram interfeysləri texnologiyalarından geniş istifadə olunur.

\section{ӘDӘBIYYAT}

[1] ISO/IEC 27001, Information technology — Security techniques Management of information and communications technology security Requrements ,2005, edition 1,36 p

[2] В. Ф. Очков, Ко Ко Чжо. Облачные функции - новый этап информационной поддержки науки и техники // Cloud of Science. 2014. T. 1. № 1. C. 5-16.

[3] SP800-145, The NIST Definition of Cloud Computing, 2011, 3 p.

[4] ISO/IEC 14360, Information technology -- Test methods for measuring conformance to Open Systems Interconnection (OSI) abstract data manipulation - Application Program Interface (API), 1996, 23 p. 